\title{
СТРАТЕГIÏ МЕТАКОГНІТІВНОГО РОЗВИТКУ МАЙБУТНІХ УЧИТЕЛІВ ПРИРОДНИЧИХ ДИСЦИПЛІН
}

\author{
Плющц В. М., к. п. н. \\ Бохан Ю. В., к. х. н. \\ Форостовська Т. О., викладач
}

Украӥна, м. Кропивницький

Центральноукраїнський державний педагогічний університет ім. В. Винниченка

DOI: https://doi.org/10.31435/rsglobal_ws/30082018/6074

\section{ARTICLE INFO}

Received: 18 July 2018

Accepted: 17 August 2018

Published: 30 August 2018

\section{KEYWORDS}

metacognition, metacognitive strategies, future teachers, professional training.

\begin{abstract}
The article discusses studies of the student's metacognition. The scientific approaches which are characterized reflect the problem of the research. The article attempts to define the place of the students in the pedagogical process and to identify the role of metakognitsy as a factor of success in vocational training.

Metacognitive knowledge, covering knowledge of a subject, knowledge about the subject and about its cognition, about oneself and once own development in this process, is the most effective with relation to cognitive and personal development of a student.

The paper states that the formation of metacognitive skills in future teacher's does not occur spontaneously, but requires the specific program - metacognitive training. Conclusion is made that the development of metacognitive abilities of students in the learning process provides control and prediction of their intellectual and creative activity. It is assumed that entering metacognitive stance will allow students to overcome the difficulties of their development and manage their own resources.
\end{abstract}

Citation: Плющ В. М., Бохан Ю. В., Форостовська Т. О. (2018) Stratehii Metakohnitivnoho Rozvytku Maibutnikh Uchyteliv Pryrodnychykh Dystsyplin. World Science. 8(36), Vol.3. doi: 10.31435/rsglobal_ws/30082018/6074

Copyright: ( 2018 Плющ В. М., Бохан Ю. В., Форостовська Т. О. This is an open-access article distributed under the terms of the Creative Commons Attribution License (CC BY). The use, distribution or reproduction in other forums is permitted, provided the original author(s) or licensor are credited and that the original publication in this journal is cited, in accordance with accepted academic practice. No use, distribution or reproduction is permitted which does not comply with these terms.

Вступ. Сучасна освітня парадигма адаптується до змін, що відбуваються у суспільстві, а основні педагогічні стратегії потребують удосконалення. Основна проблема сучасної освіти полягає у тому, що різке збільшення об'єму інформації далеко не завжди супроводжується іiі систематизацією та засвоєнням, а отримані суб'єктом під час навчальної діяльності знання не стимулюють творчу діяльність суб'єкта. Аналіз літератури з окресленої проблеми дає підстави стверджувати, що впровадження в педагогічну практику стратегій метакогнітивного розвитку створює умови, необхідні для творчої діяльності суб'єктів навчання.

Дослідженням теоретичних та практичних основ ефективної організації навчання студентів на основі метакогнітивного підходу займаються вітчизняні (Ю. А. Адоньєва, О. І. Генісаретський, Ю. В. Громико, А. О. Деркач, А. В. Карпов А. П. Сманцер) та зарубіжні вчені (А. Базен, А. Браун, Б.-М. Барт, М. Гранжа, Ж. Є. Гомбер, М. Роменвілль, Дж. Флейвелл тощо).

Результати дослідження. Здійснений аналіз психолого-педагогічної літератури засвідчив варіативність i різноплановість наукових підходів до розуміння сутності метапізнання, метакогніцій як: особливого пізнавального процесу, спрямованого на усвідомлення людиною власної когнітивної діяльності (Дж. Флейвелл); специфічної активності, що забезпечує моніторинг та оцінку людиною свого прогресу у навчанні (А. Браун); 
ментальних структур, що здійснюють недовільну регуляцію процесу переробки інформації, а також довільну організацію інтелектуальної активності самої людини (М. О. Холодна); особливих пізнавальних процесів, спрямованих на пізнання людиною піi суб'єктивної реальності, внутрішнього світу, що мають метасистемний статус (А. В. Карпов) [3].

В дослідженні Ю.А. Адоньєвої наголошується, що метапізнання є універсальною функцією, особливим пізнавальним процесом, що забезпечує якість як мисленнєвої, так і усієї предметної діяльності людини; його основною функцією $\epsilon$ контроль та регуляція усіх пізнавальних процесів; змістом метакогніцій є знання, здатності, інформація про пізнавальні процеси, тому саме вони забезпечують перебіг усієї розумової діяльності людини; метакогніції $\epsilon$ головними чинниками ефективності пізнавальної діяльності людини, що виявляються у: знаннях та контролі за власним мисленнєвим процесом та навчально-професійною діяльністю; усвідомленні власної розумової діяльності та змісту системи уявлень; моніторингу процесу мислення для його активізації, прийняття рішення [1].

На відміну від когнітивних стратегій, пов'язаних із вилученням та аналізом інформації, метакогнітивні стратегії застосовуються безпосередньо до когнітивних стратегій [2]. У дослідженнях Т. Є.Чернокової метакогнітивну стратегію визначено через: визнання неефективності початкової стратегії вирішення завдання і перехід до іï перетворення, який здійснюється через діалектичну дію зміни альтернативи; перетворення вихідної стратегії, що може здійснюватися: а)шляхом трансформації однієї раніше знайденої стратегії за допомогою діалектичних розумових дій перетворення або обігу; шляхом трансформації двох або декількох раніше знайдених стратегій за допомогою діалектичної розумової дії об'єднання [2].

Проведений аналіз сучасного стану традиційного процесу навчання майбутніх вчителів природничих дисциплін (хімії, фізики та біологіï) в закладах вищої освіти показав, що при викладанні фахових природничих дисциплін мають місце такі недоліки:

- знання більшості випускників мають формальний характер і складаються переважно з догматично засвоєних відомостей;

- слабка орієнтація на майбутню професійну діяльність, слабка методична підтримка формування у майбутніх вчителів методичної компетентності в процесі їх вивчення;

- навчально-методична література недостатньо враховує специфіку професійної діяльності майбутнього вчителя природничих дисциплін в сучасному інформаційному суспільстві, в якому знання та інформація є провідним рушієм розвитку;

- розділення як у часі, так і у предметі вивчення природничих (спрямованих на формування тільки предметних знань і умінь) і методичних (формують методичні вміння на предметному матеріалі шкільного курсу хімії, фізики та біології) дисциплін;

- недостатній рівень професійних навичок, пов’язаних 3 формуванням у майбутніх вчителів умінь і навичок використання засобів інформаційно-комунікаційних технологій.

Ми вважаємо, що проблема недостатнього рівня у майбутніх вчителів знань, умінь і навичок полягає у неспроможності адекватного вибору навчальних стратегій. Труднощі студентів виникають на рівні функції когнітивного регулювання: передбачення, планування, контролю. Цінність метакогніції полягає в тому, що з моменту їх сформованості рефлексія студента над власними когніціями знімається, оскільки вони стають предметом нерефлексивного смислового сприйняття. Таким чином на відміну від знань процеси когнітивної регуляції не завжди мають усвідомлений характер, і можуть бути результатом автоматичного застосування раніше набутого когнітивного досвіду.

В дослідженнях зарубіжних вчених сформовано перелік метакогніцій, якими має оволодіти майбутній вчитель. Так, наприклад, Ж.-Л. Вольфс враховуючі діяльнісний аспект метакогнітивного підходу пропонує розвивати наступі метакогніції майбутніх учителів:

- здатність обирати, описувати та обгрунтовувати стратегіі, які використовуються для вирішення навчальних завдань (наприклад, запропонувати пояснити, як студенти досягли розв’язку задачі);

- здатність до метакогнітивного аналізу взаємозв'язку стратегій та особистісних якостей суб'єкта, стратегій і зовнішніх факторів (ступінь складності задачі, обмеження в часі) (наприклад запропонувати порівняти стратегії, які вони використовували в ситуації А і Б);

- здатність до планування (передбачення) результатів метакогнітивної діяльності і до планування стратегій з досягнення поставленої мети; здатність приймати до уваги когнітивні, афективні та соціокультурні особливості інших суб’єктів (наприклад пояснення матеріалу відбувається інакше для учня, який був відсутнім на попередньому уроці);

- здатність до самооцінки з урахуванням не лише власної мета когнітивної поведінки, 
а й зовнішніх факторів (наприклад, оцінка впливу стилю і поведінки вчителя на учнів, на формування кінцевої мети уроку);

- здатність до метакогнітивного саморегулювання, що полягає в обробці суб'єктом інформації про власне когнітивне функціонування, співставлення свого актуального i попереднього рівнів. Запропоновані дії дозволяють підвищити ефективність стратегій педагогічної діяльності [6].

Отже, метакогнітивний досвід - складний афективнокогнітивний комплекс, що забезпечує включеність індивіда у різні види діяльності, який забезпечує метакогнітивну оцінку реалізованих дій: міру розуміння інформації, складності актуалізації матеріалу, успішності досягнення мети [2]. На думку A. L. Brown, метакогнітивний досвід виконує такі функції, як контроль, планування, регуляція та узгодження метапізнання. S. Paris, P.Winograd розкривають сутність метакогнітивного досвіду через такі його структурні компоненти, як пізнавальні якості та здібності [2].

Для планування діяльності, відстеження процесу рішення та результатів необхідно формувати метакомпоненти, в, які містять: встановлення існування проблеми; прийняття рішення щодо сутності проблеми; вибір процесів нижчого рівня для іiі вирішення; вибір стратегії; відбір ментальної репрезентації, грунтуючись на якій, компоненти та стратегії можуть діяти; розподіл власних розумових ресурсів; контроль за ходом вирішення проблеми; оцінку ефективності вирішення проблеми після завершення діяльності [2].

У дослідженнях зарубіжних учених виокремлюються декілька ефективних програм метакогнітивного навчання студентів взагалі та вчителів зокрема [1]. Наприклад, швейцарськими вченими А.-А. Дуденом, Д. Мартеном та професором Гарвардського університету Ф. Понсом розроблена та реалізується на практиці метакогнітивна програма підготовки студентів саме педагогічних спеціальностей. Ї̈̈ метою $є$ оволодіння знаннями про когнітивне функціонування, розширення можливих стратегій і послідовна реалізація на практиці внутрі- та міждисциплінарних зв’язків. Програма курсу метаконгітивної підготовки включає п'ять модулів:

1. Активізація метазнань про власні когнітивні стани; усвідомлення навчальних стратегій підготовки до екзаменів.

2. Рефлексія студента про власні когнітивні дії та дії інших суб’єктів.

3. Розвиток трансфертних здібностей, тобто здібностей використовувати стратегію вирішення конкретних навчальних задач в іншому навчальному контексті.

4. Розширення реєстру навчальних стратегій.

5. Метакогнітивна рефлексія студентів про результати вивчення метакогнітивного курсу [4].

Таким чином, при підготовці інтегрованих вчителів природничих дисциплін можна використовувати такі траєкторії метаконгітивної підготовки:

- можливість проектування кожному студенту власної траєкторії метакогнітивного навчання у відкритій системі інтегрованої природничої освіти;

- кардинальна зміна організації самого процесу пізнання, зміщення його в бік системного мислення та самостійного розв'язування професійних задач шляхом демонстрації метакогнітивних технік;

- можливість організації активної пізнавальної діяльності індивіду в ході процесу навчання з використанням навчальних, комунікативних та метакогнітівного стратегій;

- можливість здійснення дистанційного навчання різного рівня 3 використанням метакогнітивної педагогічної підтримки тощо [5].

Узагальнюючи дані досліджень з проблеми, ми дійшли до висновку про те, що педагогічна підтримка метакогнітівного розвитку майбутніх вчителів природничих дисциплін в процесі організації навчальної процесу повинна пронизувати всі види діяльності студента i модифікувати роль викладача на кожному етапі. На цій підставі вважаємо виправданим виділення діагностичного, мотиваційно-стратегічного, формувального, розвивального, корегувального, контрольно-діагностуючого та ре флексійного етапів педагогічної підтримки метакогнітівного розвитку студентів, як процесу (табл.1). 
Таблиця 1. Етапи педагогічної підтримки метакогнітивної навчальної траєкторії майбутніх вчителів природничих дисциплін

\begin{tabular}{|c|c|c|}
\hline Етапи & Змістовна характеристика етапів & Роль викладача \\
\hline Діагностичний & $\begin{array}{l}\text { Підготовча стадія (моніторинг стану } \\
\text { метакогнітівного досвіду викладача, } \\
\text { студентів і рівня їх мотивації тощо). }\end{array}$ & $\begin{array}{lr}\text { Викладач - diazносm } & \text { програми } \\
\text { метакогнітівного } & \text { розвитку. } \\
\text { Проведення } & \text { діагностики та } \\
\text { самодіагностики } & \text { метакогнітівного } \\
\text { досвіду викладача, студентів і рівня } \\
\text { їх мотивації. }\end{array}$ \\
\hline $\begin{array}{l}\text { Мотивац } \\
\text { стратегіч }\end{array}$ & 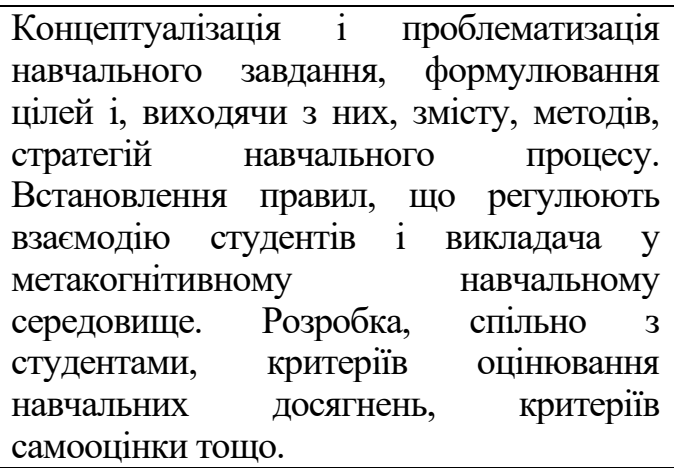 & $\begin{array}{l}\text { Викладач - мотиватор та стратед } \\
\text { програми метакогнітівного розвитку. }\end{array}$ \\
\hline $\begin{array}{l}\text { Формувальний } \\
\text { (діяльнісний) - } \\
\text { основний }\end{array}$ & 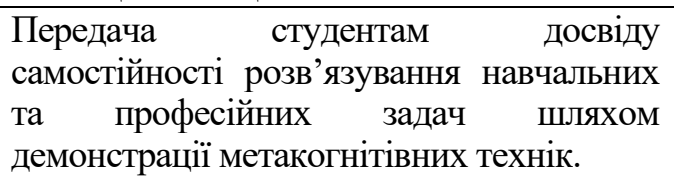 & $\begin{array}{l}\text { Викладач - медіaтор, що застосовує } \\
\text { принципи д диференціації навчання, } \\
\text { при контакті студента та } \\
\text { навчального матеріалу. }\end{array}$ \\
\hline Розвивал & $\begin{array}{l}\text { Організація умов для розвитку } \\
\text { мотиваційно-стратегічних можливостей } \\
\text { самомотивації та навчальної активності } \\
\text { студента; створення метакогнітивних } \\
\text { пауз для усвідомлення проміжних } \\
\text { результатів діяльності та пошуку шляхів } \\
\text { подолання труднощів, що виникають на } \\
\text { певних етапах. }\end{array}$ & $\begin{array}{l}\text { Викладач }- \text { актуалізатор } \\
\text { мотиваційно-стратегічних } \\
\text { можливостей самомотивації та } \\
\text { навчальної активності студента і } \\
\text { дестабілізатор звичайних уявлень } \\
\text { про навчальний процес і місце } \\
\text { студентів в ньому. }\end{array}$ \\
\hline Корегув & 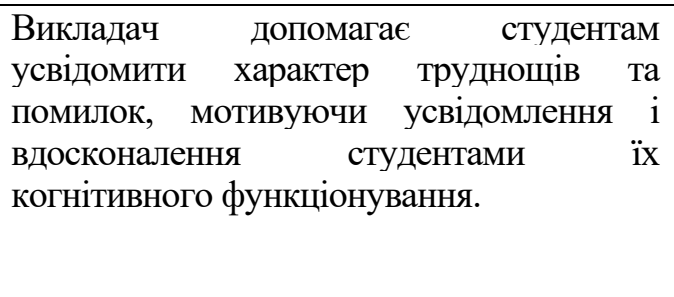 & $\begin{array}{l}\text { Викладач - гуманіст, трактує } \\
\text { помилки студентів, як природний } \\
\text { момент навчального процесу, що } \\
\text { веде до збільшення мотивації, } \\
\text { розвитку адекватної самооцінки } \\
\text { студента, високої результативності } \\
\text { його діяльності. }\end{array}$ \\
\hline $\begin{array}{l}\text { Контроль } \\
\text { діагносту }\end{array}$ & $\begin{array}{l}\text { Розвиток здібностей до саморегулювання } \\
\text { навчальної діяльності шляхом засвоєння } \\
\text { знань про власне когнітивне } \\
\text { функціонування. Оцінка продукту } \\
\text { навчальної діяльності та можливості } \\
\text { перенесення знань в інші освітні контексти. }\end{array}$ & $\begin{array}{l}\text { Викладач - mьютер, } \\
\text { використовує мотиваційно- } \\
\text { стратегічно обгрунтовані критерії } \\
\text { оцінки, й визначає способи, } \\
\text { форми і момент визначення } \\
\text { самооцінки студента та викладача, } \\
\text { вносячи корективи в самооціночну } \\
\text { діяльність студентів. }\end{array}$ \\
\hline Рефлексійний & 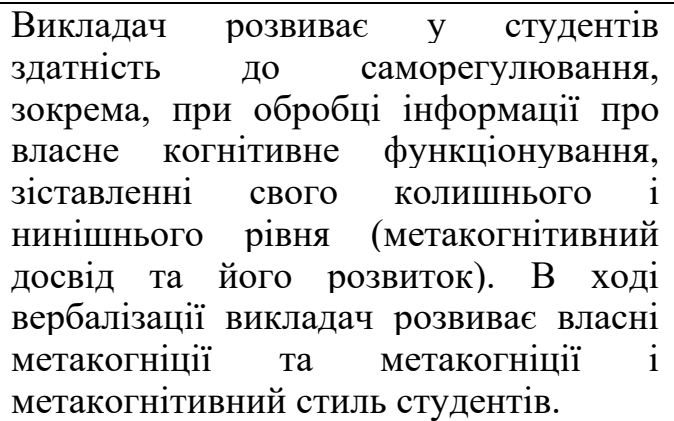 & $\begin{array}{l}\text { Викладач - pauioналізатор, щодо } \\
\text { метакогнітивного стилю } \\
\text { студентів і свого власного тощо. }\end{array}$ \\
\hline
\end{tabular}


Представлена таблиця ілюструє новий тип педагогічної взаємодії викладач - студент, необхідний в мінливому освітньому просторі національної вищої школи, який передбачає, 3 одного боку, вільну і відповідальну поведінку студента, а з іншого, змінює роль і функції викладача відповідно до етапів метакогнітівної навчальної траєкторії.

Висновки. Аналіз моделей спрямованих на розвиток метакогніцій, на формування індивідуального стиля навчальної та професійної діяльності педагога, доводить, що метакогніції дозволяють студентам відмовитись від повторення непродуктивних i нераціональних моделей навчальних дій та сприяють здійсненню особистісної самореалізації та самовдосконаленням.

Результати здійсненого аналізу досліджень зарубіжних та вітчизняних авторів дають змогу стверджувати, що розвиток метакогнітивних умінь не відбувається стихійно, а потребує цілеспрямованих формувальних програм метакогнітивного навчання.

Безперечно, в результаті застосування метакогнітивної навчальної траєкторії відбувається формування і розвиток всіх видів професійно-особистісних якостей майбутніх вчителів. Навчання метакогнітивним стратегіям дозволяє підвищити ефективність навчальної діяльності в цілому, забезпечує формування найважливішого вміння - вміння вчитися та сприяє досягненню основних освітніх стандартів. Головним надбанням використання метакогнітівної стратегій в навчанні стає розвиток здатності самостійно вчитися і здатності до безперервної самоосвіти протягом життя.

Таким чином, можна зробити висновок, що складності і проблеми передачі готових знань можливо уникнути, якщо навчити суб'єкт метакогнітивним діям, розвинути метакогнітивні здібності і допомогти тим самим набути метакогнітивного досвіду як основи для самореалізації навчальної та професійної діяльності. Отже, критерієм якості вищої освіти взагалі, та підготовки вчителів природничих дисциплін зокрема, має бути зорієнтованість навчального змісту, а також форм i методів професійної підготовки на формування метакогнітивних знань і вмінь, тобто впровадження стратегій метакогнітивногорозвитку.

\section{ЛIТЕРАТУРА}

1. Адоньєва Ю. А. Метакогнітивне навчання майбутніх фахівців у вищих навчальних закладах: досвід та особливості впровадження. ScienceRise. Pedagogical Education. 2017. № 6. С. 10-13. URL: http://nbuv.gov.ua/UJRN/ texcped_2017_6_4 (дата звернення 10.03.2018)

2. Доцевич Т. І. Метакогнітивна компетентність суб'єкта педагогічної діяльності у вищій школі. Дис... доктора психологічних наук 19.00.07 - педагогічна та вікова психологія. - Харків - 2016, 447 с.

3. Плющ В. М. Метакогнітивний підхід до організації навчання майбутніх учителів / В. М. Плющ // Вісник Чернігівського національного педагогічного університету. Серія: Педагогічні науки. - 2018. - Вип. 151 (Т.1). - С. 116 - 119.

4. Харламов И. Ф. Педагогика: Учеб. пособие. - 4-е изд., перераб. и доп. - М.: Гардарики, 2003. - 519 с.

5. Филимонова, И. Ю. Метакогнитивный компонент содержания самостоятельной работы студентов будущих учителей / И. Ю. Филимонова // Веснік МДУ ім. А. А. Куляшова. - 2009. - № 1. - С. $240-245$

6. Becher T. Academic tribes fnd territories: intellectual enquiry and the cultures of disciplines. Milton Keynes: Soc. For Research into Higher Education: Open Univ. Press, 1989. 